І.О. Трубка', З.І. Россоха' ${ }^{2}$ С.П. Кир'яченко ${ }^{2}$, Н.О. Савичук', Н.Г. Горовенко

${ }^{1}$ Національна медична академія післядипломної освіти імені П.Л. Шупика, Київ ${ }^{2}$ Д3 «Референс-центр з молекулярної діагностики МОЗ україни», Київ

\title{
Оцінка впливу генетичних предикторів на ризик розвитку хронічного генералізованого катарального гінгівіту у дітей та формування його фенотипових особливостей
}

Мета. У роботі оцінювали вплив поліморфізму генів GSTT, GSTM, IL-1及, MMP-13 у зростанні ризику розвитку хронічного генералізованого катарального гінгівіту (ХГКГ) у дітей та формування фенотипових особливостей його перебігу. Об'єкт і методи дослідження. У клінічному дослідженні взяли участь 49 дітей віком 7-15 років, яким проводили стандартне стоматологічне обстеження, біохімічний аналіз показників вмісту Са, Р, кислої та лужної фосфатаз, малонового діальдегіду, каталази у ротовій рідині, молекулярно-генетичне дослідження поліморфних варіантів генів GSTT1, GSTM1, IL-1ß (C3953T), MMP-13 (A77G) та пародонтопатогенів. Результати. Виявлено генетичні предиктори розвитку ХГКГ удітей: делеційний поліморфізм гена GSTT1, гетерозиготний

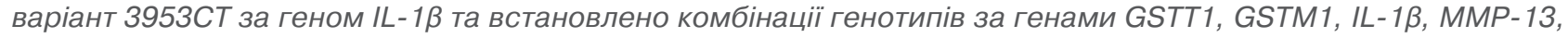
які модулюють виникнення захворювання, як підвищуючи, так і знижуючи ризик його розвитку. Визначені генетичні предиктори підвищують ризик розвитку ХГКГ у дітей за рахунок поєднаного впливу несприятливих варіантів генів з інфікуванням пародонтопатогенами: Bacteroides forsythus, Treponema denticola, Porphyromonas gingivalis. Визначено асоціацію генетичного поліморфізму з показниками антиоксидантного захисту та фосфорно-кальцієвого обміну та їх поєднаний з генетичними предикторами вплив на формування фенотипу захворювання із тяжчим перебігом.

Ключові слова: діти, хронічний генералізований катаральний гінгівіт, поліморфізм генів.

\section{Вступ}

Серед стоматологічних захворювань у дітей шкільного віку друге місце займають захворювання тканин пародонта, а саме гінгівіт, в основі якого лежить запальний процес - як відповідна реакція на вплив мікроорганізмів (пародонтопатогенів) зубного нальоту, без пошкодження зубоясеневого з'єднання (Попович З.Б., Кіндрат Г.В., 2010; Хоменко Л.О. та співавт., 2011). При несвоєчасній діагностиці та лікуванні гінгівіту створюються передумови для подальшого прогресування запалення з подальшим розвитком вже запально-деструктивних форм захворювання тканин пародонта - пародонтиту (Савичук Н.О., Марченко О.А., 2015; Хоменко Л.О. та співавт., 2015).

3 огляду на мультифакторність захворювань тканин пародонта сучасна концепція іх профілактики заснована на оцінці факторів ризику і розробці прогностичних моделей розвитку цих захворювань. Останнім часом застосування молекулярно-генетичних методів для розуміння причин підвищеного ризику розвитку цих захворювань викликає інтерес у багатьох дослідників. У окремих роботах обговорювалося, що ризик розвитку запальних захворювань тканин пародонта зумовлюється генетичним поліморфізмом (Гасюк Н.В., Єрошенко Г.А., 2013).

Для визначення генетичної детермінанти у розвитку гінгівіту у дорослих пацієнтів досліджували генетичні маркери запального процесу - поліморфізм генів IL-1 $\beta, T N F-\alpha, I L-10$, детоксикації чужорідних сполук та ендогенних метаболітів - поліморфізм генів CYP 1A1, GSTM1, GSTT1, регуляторів ендотеліальної функції - поліморфізм генів позаклітинних протеїназ MMP-1, MMP-3, MMP-9, МMP-13 (Деньга О.В. та співавт., 2014; Zhan Y. et al., 2014). Наведені варіанти генів визначені як генетичні предиктори розвитку запальних захворювань тканин пародонта у дорослих, але не вивчені у пацієнтів дитячого віку. Відповідальність за активність запальної реакції несуть інтерлейкіни (IL)-1, які виконують низку функцій в імунній системі: ініціюють і регулюють імунні процеси, беруть участь у розвитку гострого та хронічного запалення, в резорбції кісткової тканини. Сімейство IL-1 включає в себе три гомологічних білки: IL- $1 \alpha$ та - $1 \beta$, які є прозапальними і кодуються відповідними генами. У носіїв алеля 3953Т за геном IL-1 $\beta$ в гомо- та гетерозиготному станах синтезується підвищений рівень цитокіну у відповідь на певні стимули та розвивається більш інтенсивна запальна реакція зі схильністю до хронізації (Karimbux N.Y., Saraiya V.M., 2012). Знешкодження продуктів перекисного окиснення ліпідів відбувається за рахунок ензимів сімейства глутатіон-S-трансфераз (GSTs), активність яких генетично контролюється, а за наявності делеційного поліморфізму генів GSTT1, GSTM1 відповідні ізоферменти GSTs взагалі відсутні. Родину GSTs неодноразово розглядали як важливі ферменти антиоксидантного захисту клітинного рівня, від яких залежать детоксикаційні процеси (Gorovenko N.G. et al., 2010). Істотна роль у деградації міжклітинного матриксу - колагену при запаленні у тканинах пародонта належить МMP-13 (колагеназа 3), що експресується епітеліальними клітинами пародонтальних кишень у відповідь на дію різних екзогенних факторів. За наявності гетерозиготного поліморфного варіанта $A 77 G$ за геном MMP-13 спостерігається підвищення розщеплення білків міжклітинного матриксу і внаслідок цього зростає схильність до підвищеної деструкції тканин, які підтримують за фізіологічних умов зуби в яснах (Jain A., Bahuguna R., 2015). Наведені гени та їх взаємодія не вивчені у пацієнтів дитячого віку, що й зумовило проведення цього дослідження.

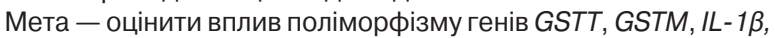
MMP-13 у зростанні ризику розвитку хронічного генералізованого катарального гінгівіту (ХГКГ) у дітей та формування фенотипових особливостей його перебігу. 


\section{Об'єкт і методи дослідження}

У клінічному дослідженні взяли участь 49 дітей віком 7-15 років. Стоматологічне обстеження дітей проводили за загальноприйнятою методикою: скарги, дані анамнезу, стоматологічний статус. Гігієнічні та пародонтальні індекси визначали відповідно до віку дитини. Гігієну порожнини рота оцінювали за допомогою спрощеного індексу (OHI-S), індексу ефективності гігієни порожнини рота (PHP), спрощеного індексу зубного нальоту O'Leary. Поширеність та інтенсивність ураження тканин пародонта - індекс РМА, для характеристики тканин пародонта і необхідності в лікуванні проводили базове пародонтальне обстеження за допомогою індексу Basic Periodontal Examination-Simplified BPE (Хоменко Л.О. та співавт., 2015).

Біохімічний аналіз ротової рідини включав показники вмісту Са, Р, кислої та лужної фосфатаз (Горячковский А.М., 2005), малонового діальдегіду (МДВ) (Гаврилов В.Б. та співавт., 1987), каталази (Королюк М.А. та співавт., 1988). Ротову рідину збирали у стерильні одноразові ємності (30-50 мл) у стані спокою протягом 10-15 хв в обсязі 10-15 мл, поміщали в термоконтейнер з охолоджувальними елементами і протягом 3 год перевозили в лабораторію.

Молекулярно-генетичне дослідження базувалося на виділенні геномної ДНК з букального епітелію та окремо ясенної рідини, забраної в ділянці ясеневої борозни для дослідження пародонтопатогенів. ДНК екстрагували з використанням набору "Quick-DNA Universal Kit» відповідно до протоколу виробника («ZymoResearch», США). Для визначення поліморфних варіантів генів GSTT1/GSTM1 застосовували метод мультиплексної ПЛР, а для генів IL-1 $\beta$ (C3953T, rs 1143634), MMP-13(A77G, rs2252070)полімеразну ланцюгову реакцію (ПЛР) з подальшим аналізом поліморфізму довжини рестрикційних фрагментів. Специфічні фрагменти генів ампліфікували комерційним набором «Master MixPCR» («NEOGEN», Україна) олігонуклеотидними праймерами («Metabion», Німеччина). Продукти ампліфікації фрагментів ДНК генів MMP-13 та IL-1 $\beta$ підлягали гідролітичному розщепленню ендонуклеазами рестрикції Bsrl, Taql («Thermo Scientific», США) відповідно. Реакцію рестрикції генів IL-1 $1 \beta$ та MMP-13 проводили в мікротермостаті при $65^{\circ} \mathrm{C}$ протягом 12 год з подальшою зупинкою реакції за кімнатної температури гена $I L-1 \beta$, підвищенням температури до $80{ }^{\circ} \mathrm{C}$ впродовж 20 хв для гена MMP-13. Стан фрагментів аналізували в 3\% агарозному гелі (агароза фірми «Cleaver Scientific», Великобританія) з додаванням бромистого

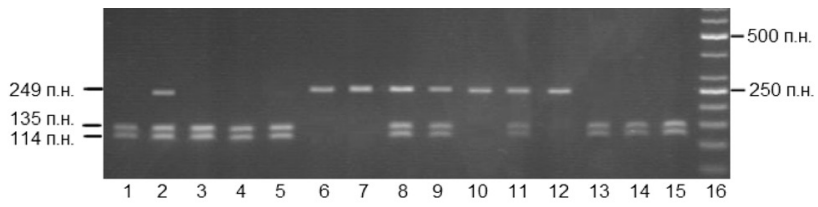

Рис. 1. Електрофореграма розподілу рестрикційних фрагментів гена $/ L-1 \beta$ Генотип 3953СС - зразки 1, 2, 4, 5, 13-15; генотип 3953СТ - зразки 2, 8, 9, 11; генотип $3953 \pi$ - зразки 6, 7, 10, 12; М - маркер молекулярної маси.

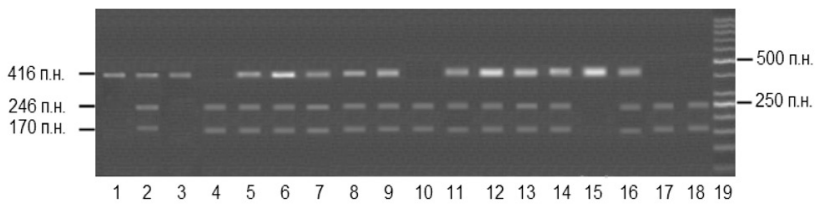

Рис. 2. Електрофореграма розподілу рестрикційних фрагментів гена MMP-13 Генотип $77 A A$ - зразки $1,3,15$; генотип $77 A G$ - зразки 2, 5-9, 11-14, 16; генотиг $77 G G$ - зразки 4, 10, 17, 18; M - маркер молекулярної маси.

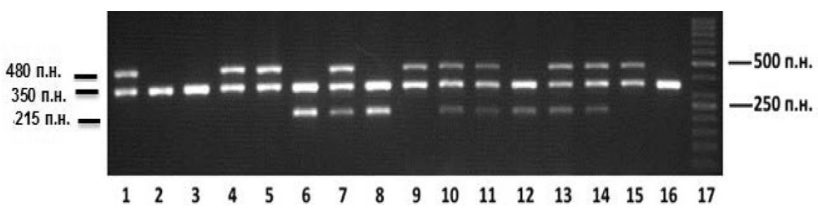

Рис. 3. Електрофореграма продуктів ампліфікації генів GSTT1/GSTM1 Генотип GSTT1 allele/GSTM1 deletion - зразки 1, 4, 5, 9, 15; генотип GSTT1 deletion/ GSTM1 allele - зразки 6, 8, 12; генотип GSTT1 deletion/GSTM1 deletion - зразки 2, 3, 16; генотип GSTT1 allele/GSTM1 allele - зразки 7, 10, 11, 13, 14. етидію. Для оцінки розміру фрагментів вносили маркер молекулярної ваги "GeneRuler 50bp DNALadder» («Thermo Scientific», США) з візуалізацією у трансілюмінаторі. Обробку отриманого зображення проводили в комп'ютерній програмі «Vitran». Ампліфіковані фрагменти гена $I L-1 \beta$ підлягали гідролітичному розщепленню за наявним сайтом рестрикції 5' -T $\downarrow$ CGA-3', внаслідок чого утворювалися фрагменти з молекулярною масою 135 п.н. та 114 п.н. - генотип 3953СС. Сайт рестрикції зникав при нуклеотидній заміні $C$ на $T$ в позиції 3953, тому при нуклеотиді $T$ розмір фрагмента ампліфікованої ділянки ДНК після дії рестриктази залишався незмінним - 249 п.н. Відповідно у гетерозигот (генотип 3953CT) на електрофореграмі спостерігали всі три довжини фрагментів водночас: 249, 135 та 114 п.н. (рис. 1)

Гідролітичне розщеплення ампліфікованої ділянки ДНК гена MMP відбувалося за наявності сайта рестрикції TGAC $\downarrow \mathrm{CN}$, внаслідок чого утворювалися фрагменти з молекулярною масою 246, 170 та 29 п.н. (генотип 77GG). Після гідролітичного розщеплення продуктів ампліфікації гена ММР фрагменти ДНК з молекулярною вагою 416 та 29 п.н. відповідали генотипу $77 A A$, з молекулярною вагою 416, 24, 170 та 29 п.н. - генотипу $77 A G$ (рис. 2).

За наявності ампліфікованого фрагмента ДНК 480 п.н. реєстрували генотип GSTT1 allele (функціональний алель), а за наявності фрагмента довжиною 215 п.н. - GSTM1 allele (функціональний алель). При відсутності зазначених фрагментів генів GSTT1 та GSTM1 виявляли варіант deletion (нефункціональний алель). Якість виділення ДНК і умови постановки ПЛР контролювали ампліфікацією фрагмента гена альбуміну з молекулярною масою 350 п.н., у разі його відсутності результати не враховували (рис. 3).

Статистичну обробку отриманих даних виконували з використанням програмних пакетів «Statistica 17.0» та «Excel 2010». Для порівняння розподілу частот генотипів у групах та підгрупах дослідження використовували описову статистику та обчислення критеріїв $\chi^{2}$ Пірсона з поправкою Йєтса. При дослідженні генфакторних взаємодій використовували метод бінарної логістичної регресії. Статистично достовірними вважали відмінності при $\mathrm{p}<0,05$.

\section{Результати та їх обговорення}

Для оцінки ролі генетичної компоненти у розвитку ХГКГу дітей обстежених розподілено на дві групи: із виявленими ознаками захворювання на момент огляду та без них (табл. 1). Розподіл генотипів за поліморфним варіантом гена GSTM1 не відрізнявся в групах порівняння. У пацієнтів зХГКГ виявлено достовірне зростання частоти нефункціонального алеля за геном GSTT1 порівняно з пацієнтами без клінічних ознак ХГКГ $\left(\chi^{2}=5,86 ; p=0,015\right.$; відносний ризик (ВР) 13,33; 95\% довірчий інтервал (ДІ) 1,51$117,4)$.

Функціональний алель за геном GSTT1, навпаки, був достовірно підвищений у групі пацієнтів без гінгівіту $\left(\chi^{2}=5,86\right.$, p=0,015; ВР 0,08; 95\% ДІ 0,01-0,66), що свідчить про протекторний ефект.

Частота поліморфного варіанта C3953T за геном IL-1 $\beta$ була підвищеною (див. табл. 1) у пацієнтів з ХГКГ порівняно з пацієнтами без ХГКГ (52,17 та 23,08\% відповідно), тобто встановлено асоціацію поліморфного варіанта $3953 C T\left(\chi^{2}=4,45\right.$; p=0,043; ВР 3,64; 95\% ДІ 1,07-12,38), так само, як і двох поліморфних варіантів 3953СТ та 3953ТТ $\left(x^{2}=4,46 ; p=0,035 ;\right.$ ВР $3,50,95 \%$ ДІ 1,07-11,4) зі зростанням ризику ХГКГ. У дітей без ХГКГ достовірно частіше переважав поліморфний варіант $3953 C C\left(x^{2}=4,46 ; p=0,038 ;\right.$ BP 0,29; 95\% ДІ 0,09-0,93), для якого визначено асоціацію зі зниженням ризику розвитку ХГКГ. Достовірних відмінностей у частоті розповсюдження генотипів за геном MMP-13 у досліджуваних групах не виявлено ( $p>0,05)$.

На наступному етапі нами оцінено сукупний вплив генів на ризик розвитку ХГКГ, для чого проаналізовано 86 можливих комбінацій генотипів за дослідженими генами. У табл. 2 представлені достовірні комбінації генотипів, які впливали на ризик розвитку ХГКГ. Встановлено, що у пацієнтів з ХГКГ, на відміну від осіб без ХГКГ, достовірно переважали комбінації нефункціонального алеля за геном GSTT1 з функціональним алелем за геном GSTM1 ( $\left.\chi^{2}=4,15 ; p=0,042\right)$. У пацієнтів без ХГКГ такої комбінації взагалі не виявлено (див. табл. 2), а також комбінації 
Таблиця 1. Розподіл поліморфних варіантів та алелів за генами GSTT1, GSTM1, IL-1ß (C3953T), MMP-13 (A77G) у обстежених дітей

\begin{tabular}{|c|c|c|c|c|c|c|c|c|c|}
\hline \multirow{2}{*}{ Ген } & \multirow{2}{*}{ Поліморфні варіанти } & \multicolumn{2}{|c|}{ Діти з ХГКГ } & \multicolumn{2}{|c|}{ Діти без ХГКГ } & \multicolumn{4}{|c|}{ Результати статистичного аналізу } \\
\hline & & n & $\%$ & n & $\%$ & $x^{2}$ & BP & 95\% ДI & p \\
\hline GSTT1 & allele & 15 & 65,22 & 25 & 96,15 & 5,86 & 0,08 & $0,01-0,66$ & 0,015 \\
\hline \multirow{2}{*}{ GSTM1 } & $\begin{array}{l}\text { deletion } \\
\text { allele }\end{array}$ & $\begin{array}{l}8 \\
8\end{array}$ & $\begin{array}{l}34,18 \\
34,78\end{array}$ & $\begin{array}{c}1 \\
12\end{array}$ & $\begin{array}{c}3,85 \\
46,15\end{array}$ & & $\begin{array}{c}13,33 \\
0,62\end{array}$ & $\begin{array}{c}1,51-111,4 \\
0,20-1,97\end{array}$ & \\
\hline & deletion & 15 & 65,22 & 14 & 53,85 & 0,27 & 1,61 & $0,51-5,09$ & 0,605 \\
\hline \multirow[t]{3}{*}{ IL-1 $\beta$ (C3953T) } & 3953CC & 9 & 39,13 & 18 & 69,23 & 4,46 & 0,29 & $0,09-0,93$ & 0,038 \\
\hline & $3953 \mathrm{CT}$ & 12 & 52,17 & 6 & 23,08 & 4,45 & 3,64 & $1,07-12,4$ & 0,043 \\
\hline & $3953 \pi T$ & 2 & 8,70 & 2 & 7,69 & 0,16 & 1,14 & $0,15-8,84$ & 0,693 \\
\hline \multirow[t]{4}{*}{ MMP-13 (A77G) } & $77 A A$ & 10 & 43,48 & 10 & 38,46 & 0,01 & 1,23 & $0,39-3,86$ & 0,948 \\
\hline & $77 A G$ & 10 & 43,48 & 10 & 38,46 & 0,01 & 1,23 & $0,39-3,86$ & 0,948 \\
\hline & $77 G G$ & 3 & 13,04 & 6 & 23,08 & 0,29 & 0,50 & $0,11-2,28$ & 0,592 \\
\hline & $77 A G+G G$ & 13 & 56,52 & 16 & 61,54 & 0,00 & 1,23 & $0,39-3,86$ & 0,948 \\
\hline
\end{tabular}

Таблиця 2. Достовірні комбінації поліморфних варіантів за генами GSTT1, GSTM1, IL-1ß, MMP-13 у обстежених дітей

\begin{tabular}{|c|c|c|c|c|c|c|c|c|}
\hline \multirow{2}{*}{ Поліморфні варіанти } & \multicolumn{2}{|c|}{ Пацієнти з ХГКГ } & \multicolumn{2}{|c|}{ Пацієнти без ХГКГ } & \multicolumn{4}{|c|}{ Результати статистичного аналізу } \\
\hline & $\mathrm{n}$ & $\%$ & $n$ & $\%$ & $x^{2}$ & BP & $95 \%$ Дl & p \\
\hline \multicolumn{9}{|c|}{ GSTT1/GSTM1 } \\
\hline GSTT1 allele/GSTM1 allele & 3 & 13,04 & 12 & 46,15 & 4,84 & 0,18 & $0,04-0,70$ & 0,028 \\
\hline T-deletion/M-allele & 5 & 21,74 & 0 & 0,00 & 4,15 & - & - & 0,042 \\
\hline \multicolumn{9}{|c|}{ GSTT1/IL-1ß (C3953T) } \\
\hline T-allele/3953CC & 6 & 26,09 & 17 & 65,38 & 6,07 & 0,19 & $0,05-0,64$ & 0,014 \\
\hline T-deletion/3953CT & 4 & 17,39 & 0 & 0,00 & 4,92 & - & - & 0,027 \\
\hline \multicolumn{9}{|c|}{ GSTM1/IL-1ß (C3953T) } \\
\hline \multicolumn{9}{|c|}{ GSTT1/MMP-13 (A77G) } \\
\hline T-deletion/77AG & 5 & 21,73 & 0 & 0,00 & 4,15 & - & - & 0,042 \\
\hline \multicolumn{9}{|c|}{ GSTT1/GSTM1/IL-1ß (C3953T) } \\
\hline T-allele/M-allele & 0 & 0,00 & 8 & 30,77 & 6,36 & - & - & 0,012 \\
\hline
\end{tabular}

нефункціонального алеля GSTT1 з поліморфним варіантом 3953CT за геном $I L-1 \beta\left(\chi^{2}=4,92 ; p=0,027\right)$ та з поліморфним варіантом 77AG за геном MMP-13 $\left(\chi^{2}=4,15 ; p=0,042\right)$. На особливу увагу заслуговує те, що останніх двох комбінацій генотипів також не виявлено у пацієнтів без ХГКГ, тобто ці комбінації генотипів, асоційовані з розвитком ХГКГ, необхідно розглядати як генетичні або предикторні маркери, за наявності яких імовірно прогнозувати ризик цього захворювання у дітей. На противагу комбінаціям генотипів, які визначали спадкову схильність до розвитку ХГКГ, нами визначено чотири варіанти комбінацій генотипів (див. табл. 2), які переважали у пацієнтів без ХГКГ та мали протективний ефект. У дітей без ХГКГ достовірно підвищена частота комбінацій функціонального алеля за генами GSTT1/GSTM1 ( $\chi^{2}=4,84 ; p=0,028 ;$ ВР 0,18; 95\% ДІ 0,04-0,70), а також функціонального алеля за геном GSTT1 у поєднанні з генотипом 3953CC за геном IL-1 $\beta\left(\chi^{2}=6,07 ; p=0,014 ; B P 0,19\right.$; $95 \%$ ДІ 0,05-0,64). Найбільший достовірний протекторний ефект встановлено для комбінації функціонального алеля за генами GSTT1, GSTM1 та поліморфним варіантом 3953CC за геном $I L-\beta\left(X^{2}=6,36 ; p=0,012\right)$.

Пацієнтів обстежено на носійство пародонтопатогенів методом ПЛР. Частота інфікування пародонтопатогенами хворих на ХГКГ дітей та без його проявів представлені у табл. 3. Оцінено взаємозв'язок інфікування наведеними збудниками з генетичними особливостями пацієнтів і станом ясен методом бінарної логістичної регресії. У пацієнтів із ХГКГ та нефункціональним алелем гена GSTT1 достовірно частіше виявляли пародонтопатогени Prevotella intermedia $(\mathrm{p}=0,015)$, Treponema denticola $(p=0,003)$ та Porphyromonas gingivalis $(p=0,047)$. Виявлено комбінацію поліморфного варіанта 3953CT за геном IL- $\beta$ та пародонтопатогенів Bacteroides forsythus $(p=0,024)$ та Porphyromonas gingivalis ( $\mathrm{p}=0,041)$. Отже, за наявності визначених нами генетичних маркерів пацієнти з ХГКГ були достовірно частіше інфіковані пародонтопатогенами з червоного та помаранчевого комплексу.

При проведенні оцінки біохімічних показників слини залежно від поліморфізму генів GSTT1 та MMP-13 достовірних відмінностей не виявлено ( $p>0,05)$, тоді як для гена GSTM1 встановлено підвищення рівня кислої фосфатази за наявності функціонального $(0,92 \pm 0,17)$ та делеційного поліморфізму $(0,65 \pm 0,11)$ у групі з ХГКГ порівняно з цими показниками у групі без ХГКГ $(0,53 \pm 0,09$

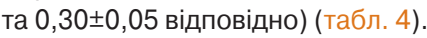

Достовірно гіршим був РНР у групі дітей з ХГКГ $(2,28 \pm 0,22)$ порівно з групою без ХГКГ $(1,58 \pm 0,26)$. Для дітей з ХГКГ характерне зниження показника фосфору за наявності алеля 3953Т в гомо- та гетерозиготному станах $(4,74 \pm 0,44)$ порівняно з генотипом 3953CC $(6,72 \pm 0,49)$ за геном $I L-\beta$. Показник МДА підвищений у групі дітей з ХГКГ та алелем 3953 Т $(0,86 \pm 0,31)$ порівняно з показником у групі дітей безХГКГ $(0,21 \pm 0,06)$ за геном IL 1 - $\beta$ (табл. 5)

Таблиця 3. Частота інфікування дітей пародонтопатогенами, \%

\begin{tabular}{lccccc}
\hline & \multicolumn{5}{c}{ Пародонтопатогени } \\
\cline { 2 - 6 } Група & $\begin{array}{c}\text { Aggre- } \\
\text { Prevotella } \\
\text { intermedia }\end{array}$ & Bacteroides Treponema & $\begin{array}{c}\text { fatibacter } \\
\text { actino- } \\
\text { mycetem- }\end{array}$ & $\begin{array}{c}\text { Porphyro- } \\
\text { monas } \\
\text { gingivalis } \\
\text { comitans }\end{array}$ \\
\hline Діти без ХГКГ & - & 28,6 & - & 85,7 & 28,6 \\
Діти 3 ХГКГ & 21,1 & 47,4 & 42,1 & 94,7 & 47,4 \\
Усього & $\mathbf{1 2 , 1}$ & $\mathbf{3 9 , 4}$ & $\mathbf{2 4 , 2}$ & $\mathbf{9 0 , 9}$ & $\mathbf{3 9 , 4}$ \\
\hline
\end{tabular}

Таблиця 4. Біохімічні показники залежно від поліморфізму за геном GSTM1

\begin{tabular}{|c|c|c|c|c|}
\hline \multirow{2}{*}{ Показник } & \multicolumn{2}{|c|}{ Група з ХГКГ } & \multicolumn{2}{|c|}{ Група без ХГКГ } \\
\hline & allele & deletion & allele & deletion \\
\hline \multicolumn{5}{|c|}{ Біохімічні показники } \\
\hline Кальцій, ммоль/л & $0,92 \pm 023$ & $0,70 \pm 0,13$ & $0,72 \pm 0,16$ & $0,47 \pm 0,15$ \\
\hline Фосфор, мг/дл & $5,02 \pm 0,78$ & $5,56 \pm 0,44$ & $5,12 \pm 0,40$ & $5,11 \pm 0,28$ \\
\hline Кисла фосфатаза, Од/л & $0,92 \pm 0,17$ & $0,65 \pm 0,11$ & $0,53 \pm 0,09$ & $0,30 \pm 0,05$ \\
\hline Лужна фосфатаза, 0 д/л & $0,85 \pm 0,13$ & $0,65 \pm 0,14$ & $0,50 \pm 0,09$ & $0,41 \pm 0,05$ \\
\hline Каталаза, мкат/г білка & $8,79 \pm 4,9$ & $7,17 \pm 1,28$ & $3,64 \pm 0,89$ & $10,59 \pm 1,54$ \\
\hline МДА, мкмоль/л & $1,13 \pm 0,57$ & $0,49 \pm 0,08$ & $0,49 \pm 0,07$ & $0,54 \pm 0,16$ \\
\hline \multicolumn{5}{|c|}{ Клінічні показники } \\
\hline PMA, \% & 19 & 21 & - & - \\
\hline G-V & $1,72 \pm 0,10$ & $1,87 \pm 0,09$ & $1,58 \pm 0,15$ & $1,27 \pm 0,10$ \\
\hline $\mathrm{OL}$ & $0,32 \pm 0,02$ & $0,45 \pm 0,04$ & $0,35 \pm 0,04$ & $0,32 \pm 0,05$ \\
\hline PHP & $1,84 \pm 0,07$ & $2,28 \pm 0,22$ & $2,12 \pm 0,21$ & $1,58 \pm 0,26$ \\
\hline
\end{tabular}

Таблиця 5. Біохімічні показники слини залежно від поліморфізму Сз953Т за геном $I L-1 \beta$

\begin{tabular}{|c|c|c|c|c|}
\hline \multirow{2}{*}{ Показник, одиниці } & \multicolumn{2}{|c|}{ Група з гінгівітом } & \multicolumn{2}{|c|}{ Група без гінгівіту } \\
\hline & CC & $\mathrm{CT}+\mathrm{TT}$ & CC & $\mathrm{CT}+\mathrm{TT}$ \\
\hline \multicolumn{5}{|c|}{ Біохімічні показники } \\
\hline Кальцій, ммоль/л & $0,91 \pm 0,16$ & $0,72 \pm 0,15$ & $0,67 \pm 0,13$ & $0,40 \pm 0,10$ \\
\hline Фосфор, мг/дл & $6,72 \pm 0,49 *$ & $4,74 \pm 0,44^{\star *}$ & & $=0,07$ \\
\hline Кисла фосфатаза, Од./л & $0,80 \pm 0,17$ & $0,72 \pm 0,12$ & $0,44 \pm 0,07$ & $0,39 \pm 0,06$ \\
\hline Лужна фосфатаза, Од./л & $0,82 \pm 0,26$ & $0,68 \pm 0,09$ & $0,45 \pm 0,05$ & $0,49 \pm 0,13$ \\
\hline Каталаза, мкат/г білка & $4,51 \pm 1,33$ & $9,27 \pm 2,64$ & $6,59 \pm 1,24$ & $6,72 \pm 2,75$ \\
\hline МДА, М & $0,43 \pm 0,10$ & $0,86 \pm 0,31^{*}$ & 50,08 & $0,21 \pm 0,06^{*}$ \\
\hline \multicolumn{5}{|c|}{ Клінічні показники } \\
\hline PMA, \% & 23 & 19 & - & - \\
\hline G-V & $1,76 \pm 0,05$ & $1,85 \pm 0,11$ & $1,32 \pm 0,12$ & $1,62 \pm 0,09$ \\
\hline $\mathrm{OL}$ & $0,40 \pm 0,02$ & $0,41 \pm 0,04$ & $0,31 \pm 0,03$ & $0,38 \pm 0,06$ \\
\hline PHP & $2,09 \pm 0,16$ & $2,15 \pm 0,23$ & $1,75 \pm 0,21$ & $1,62 \pm 0,09$ \\
\hline
\end{tabular}


Отже, досліджені гени мали достовірний вплив на показники антиоксидантного захисту та фосфорно-кальцієвого обміну. Зазначимо, що у дітей із несприятливими комбінаціями генотипів за геном GSTM1 спостерігали вищу поширеність та інтенсивність ураження тканин пародонта (індекс РМА) i, відповідно, гірші показники гігієнічного догляду за порожниною рота (див. табл. 4). Результат аналізу клінічних проявів у дітей з ХГКГ свідчить, що за наявності алеля 3953CC за геном $L-\beta$ переважно діагностовано легкий ступінь перебігу ХГКГ $(66,7 \%)$, середній ступінь тяжкості виявлено у 33,3\% дітей відповідно. За наявності алеля 3953Т в гомо- та гетерозиготному станах у більшості випадків спостерігали середній ступінь тяжкості $(64,3 \%)$ і лише у 35,7\% дітей - легкий ступінь перебігу ХГКГ. Тяжчий перебіг захворювання відбувався на фоні підвищення процесів оксидативного стресу, зниження показників фосфорно-кальцієвого обміну, виявленого інфікування пародонтопатогенами та супроводжувався здебільшого вираженою кровоточивістю ясен під час чищення зубів.

\section{Висновки}

1. Виявлено генетичні предиктори розвитку ХГКГ у дітей: делеційний поліморфізм гена GSTT1, гетерозиготний варіант 3953CT за геном $I L-1 \beta$ та встановлено комбінації генотипів за генами GSTT1, GSTM1, IL-1 $\beta$ (C3953T), MMP-13 (A77G), які модулюють виникнення захворювання, як підвищуючи, так і знижуючи ризик його розвитку.

2. 3'ясовано, що визначені генетичні предиктори підвищують ризик розвитку захворювання на ХГКГ у дітей за рахунок поєднаного впливу несприятливих варіантів генів з інфікуванням пародонтопатогенами з червоного та помаранчевого комплексу: Bacteroides forsythus, Treponema denticola, Porphyromonas gingivalis.

3. Визначено асоціацію генетичного поліморфізму з показниками антиоксидантного захисту та фосфорно-кальцієвого обміну та їх поєднаний з генетичними предикторами вплив на формування фенотипу захворювання із тяжчим перебігом.

\section{Список використаної літератури}

Гаврилов В.Б., Гаврилова А.Р., Мажуль М.Н. (1987) Анализ методов определения продуктов перикисного окисления липидов в сыворотке крови по тесту с тиобарбитуровой кислотой. Вопр. медхимии, 1: 118-122.

Гасюк Н.В., Єрошенко Г.А. (2013) Сучасні уявлення про етіологію та патогенез хвороб пародонта. Світ мед. біол., 2: 207-211.

Горячковский А.М. (2005) Клиническая биохимия в лабораторной диагностике. Одесса, Экология, 607 с.

Деньга О.В., Ефремова О.В., Вербицкая Т.Г. (2014) Молекулярногенетическая оценка предрасположенности работников химической промышленности к стоматологическим заболеваниям. Іннов. стоматол., 4: $56-61$.

Королюк М.А., Иванова Л.И., Майорова И.Г., Токарев В.Е. (1988) Метод определения активности каталазы. Лаб. дело, 1: 16-19.

Попович З.Б., Кіндрат Г.В. (2010) Поширеність захворювань пародонту у дітей, які проживають на екологічно забруднених територіях. Вісн. стоматол., 2: 32-33.

Савичук Н. О., Марченко О.А. (2015) Дисбиоз и воспаление в комплексной терапии хронического генерализованного катарального гингивита у детей школьного возраста. Совр. стоматол., 3: 46-50.

Хоменко Л.0., Голубєва І.М., Остапко О.І. (2015) Терапевтична стоматологія дитячого віку. Книга плюс, Київ, 329 с.

Хоменко Л.О., Остапко О.І., Дуда О.В. (2011) Екологічні аспекти стоматологічних захворювань у дітей. Клін. стоматол., 1-2: 53-63.

Gorovenko N.G., Rossokha Z.I., Podolskaya S.V. et al. (2010) The role of genetic determinant in the development of severe perinatal asphyxia. Tsitol. Genet., 44(5): 41-46.

Jain A., Bahuguna R. (2015) Role of matrix metalloproteinase in denta caries, pulp and periapicalinflammation: an overview. J. Oral Biol. Craniofacial. Res., 5(3): 212-218.

Karimbux N.Y., Saraiya V.M. (2012) Interleukin-1 gene polymorphisms and chronic periodontitis in adult whites: a systematic review and meta-analysis. J. Periodontol., 83(11): 1407-1419.

Zhan Y., Zhang R., Song X. (2014) Prioritization of candidate genes for periodontitis using multiple computational tools. J. Periodontol., 85(8): 10591069

\section{Оценка влияния генетических}

\section{предикторов на риск развития}

\section{хронического генерализованного}

катарального гингивита у детей

и формирование его фенотипических особенностей

\section{И.А. Трубка, З.И. Россоха, С.П. Кирьяченко Н.О. Савичук, Н.Г. Горовенко}

Резюме. Цель. В работе оценивали влияние полиморфизма генов GSTT, GSTM, IL-1及, MMP-13 на риск развития хронического генерализованного катарального гингивита (ХГКГ) у детей и формирование фенотипическихособенностей его течения. Объект и методы исследования. В клиническом исследовании приняли участие 49 детей в возрасте 7-15 лет, которым проводили стандартное стоматологическое обследование, биохимический анализ показателей содержания $\mathrm{Ca}, \mathrm{P}$, кислой и щелочной фосфатаз, малонового диальдегида, каталазы в ротовой жидкости, молекулярно-генетическое исследование полиморфных вариантов генов GSTT1, GSTM1, IL-1及 (C3953T), MMP-13 (A77G) и пародонтопатогенов. Результати. Выявлены генетические предикторы развития ХГКГ у детей: делеционный полиморфизм гена GSTT1, гетерозиготный вариант 3953CT по гену IL-1ß и установлено комбинации генотипов по генам GSTT1, GSTM1, IL-1ß, MMP-13, которые модулируют возникновение заболевания, как повышая, так и снижая риск его развития. Исследуемые генетические предикторы повышают риск развития заболевания ХГКГ у детей за счет сочетанного воздействия неблагоприятных вариантов генов с инфицированием пародонтопатогенами: Bacteroides forsythus, Treponemadenticola, Porphyromonas gingivalis. Определены ассоциации генетического полиморфизма с показателями антиоксидантной защиты и фосфорно-кальциевого обмена и их общее с генетическими предикторами влияние на формирование фенотипа заболевания с более тяжелым течением.

Ключевые слова: дети, хронический генерализованный катаральный гингивит, полиморфизм генов.

\section{Evaluation of genetic predictors influence on development risk of chronic generalized catherine gynivitis in children with formation of its phenotypic features \\ I.O. Trubka, Z.I. Rossokha, S.P. Kyriachenko, N.O. Savychuk, N.G. Gorovenko}

Summary. The effect of GSTT1, GSTM1, IL-1 $\beta$, MMP-13 genes polymorphism on increased development risk of chronic generalized catarrhal gingivitis (CGCG) in children and formation of its phenotypic features was evaluated in this work. Clinical study included standard dental examination of 49 school children aged 7-15 years. All children were undergoing $\mathrm{Ca}, \mathrm{P}$, acid and alkaline phosphatase, malondialdehyde, catalase biochemical analysis in the oral liquid and molecular genetic study of periodontal pathogens and GSTT1, GSTM1, IL-13 (C3953T), MMP-13 (A77G) polymorphic gene variants. HGKG genetic predictors in children have been identified: deletion polymorphism in GSTT1 gene, 3953CT heterozygous variant in IL-1 $\beta$ gene and genotypes combinations of GSTT1,GSTM1,IL-1 3, MMP-13 genes, which modulated disease onset included increased development risk or its decreased. Identified genetic predictors increased HGCG development risk in children due to the combined effects of adverse genes variants with paradontopathogenic infections: Bacteroides forsythus, Treponema denticola, Porphyromonas gingivalis. Genetic polymorphism associated with antioxidant defense and phosphoric-calcium metabolism indicators and their complex influenced on formation of disease phenotype with severe course.

Key words: children, chronic generalized catarrhal gingivitis, genes polymorphism.

\section{Адреса для листування:}

Трубка Ірина Олександрівна

04112, Київ, вул. Дорогожицька, 9

Національна медична академія

післядипломної освіти імені П.Л. Шупика,

кафедра стоматології дитячого віку

E-mail: itrubka@ukr.net 